Braye, S., Dixon, K. and Gibbons, T. (2017) Disabled athletes as outsiders to English sporting national identity. In T. Gibbons \& D. Malcolm (Eds.) Sport and English National Identity. London, Routledge.

\title{
Chapter 9: Disabled athletes as outsiders to English sporting national identity
}

\author{
By Stuart Braye, Tom Gibbons \& Kevin Dixon
}

(Teesside University)

\section{Introduction}

In this chapter we focus on the relationship between disability, sport and English national identity to reveal a narrative of exclusion, discrimination and disenchantment. Whilst the British media, disability sports organisations (DSOs), politicians and academics have argued that the London 2012 Paralympics and its legacy have had a positive impact upon popular attitudes towards disabled people in England both within and outside of the sporting sphere, we argue that the reality is that negative attitudes towards disabled people persist just as they did prior to the Games (see Braye, Dixon, Gibbons 2013; 2015). The real legacy for disabled people in England is one of stagnation and disempowerment with disabled individuals long considered outsiders to the English "imagined community" (Anderson 1991). We suggest that this negative and enduring legacy is implicit throughout the structure of English sport.

In what follows we begin by revealing our theoretical steer by introducing Elias and Scotson's (1965/1994) "established-outsider relations". This approach, which has only been considered briefly by others in the context of disability sport (see Smith and Thomas 2015; Thomas and Smith 2009), is used throughout this chapter to help explain the relationship between disabled athletes, sport and English national identity. 


\section{Established-Outsider relations}

In a study on a small community within England, referred to as "Winston Parva", Elias and Scotson (1994) greatly developed the theory of established-outsider relations. Their research into 'a suburban community' revealed there to exist:

a sharp division... between an old-established group and a newer group of residents, whose members were treated as outsiders by the established group. The latter closed ranks against them and stigmatized them generally as people of lesser human worth. They were thought to lack the superior human virtue-the distinguishing group charismawhich the dominant group attributed to itself (Elias and Scotson 1994: $x v)$.

Elias and Scotson were keen to stress that the findings of their small case study were a microcosm of the situation in many other areas of society where more powerful social groups often consider themselves to be 'better' than less powerful ones and that 'the "superior" people may make the less powerful people themselves feel that they lack virtue - that they are inferior in human terms' (Ibid: xvi). In one example Elias and Scotson (1994: xliii-xliv) demonstrate how established-outsider relations become manifest in the character of some nationally-oriented groupings which regard themselves as the most "established":

A striking example in our time is that of the we-image and we-ideal of once-powerful nations whose superiority in relation to others has 
declined. Their members may suffer for centuries because the group charismatic we-ideal, modelled on an idealized image of themselves in the days of their greatness, lingers on for many generations as a model they feel they ought to live up to, without being able to do so. The radiance of their collective life as a nation has gone; their power superiority in relation to other groups, emotionally understood as a sign of their own higher human value in relation to the inferior value of these others, is irretrievably lost. Yet, the dream of their special charisma is kept alive in a variety of ways-through the teaching of history, the old buildings, masterpieces of the nation in the time of its glory, or through new achievements which seemingly confirm the greatness of the past.

Established-outsider relations has specifically been applied along these lines to help explain the strength of the relationship between English national identity and sport. Maguire and Poulton's (1999) study focused on the relationship between sport, national identity and the English press during the 1996 European Football Championships (Euro 96). Here the authors made use of established-outsider relations (alongside other theories) to explain how the English media use sporting contests to highlight divisions between national cultures. They showed how particular narratives were used by the English press to reinforce and preserve an "us" versus "them" dichotomy between the English and their opponent nations using national stereotypes in an attempt to maintain their assumed "established" position. Gibbons' (2010; 2014) research has also shown how past English/British achievements both sporting (such as winning the 1966 football World Cup), and non-sporting (such as the winning of the two world wars and the existence of the once globally powerful former 
British Empire), have often been referred to by the English press and English football fans to exert a sense of English national superiority over other nations, particularly those with which Britain has been at war (see also Chapter 3). The notion of athletes being 'proxy warriors' (Hoberman 1984) for their nation as they participate in the 'proxy war' of sport is especially strong in English media depictions of male international sport. Conversely, disabled athletes have rarely been depicted as representatives of their nation and instead are celebrated by the media as individuals who have overcome adversity. For instance, two disabled activist participants in previous research highlight this point:

The media likes heartbreaking stories, but they convey them so pathetically that it's bad telly (George in Braye, Dixon \& Gibbons 2013: 993).

Some of the TV coverage of the Paralympics is good but still has a feel of 'oh isn't it a shame, look at the poor cripple' it just makes non-disabled people see disabled people as 'brave' or 'courageous' (Faith in Braye, Dixon \& Gibbons 2013: 993).

Canadian Paralympian Danielle Peers' (2009) view is that disabled people are portrayed as heroic and tragic simultaneously. In this sense, the power of the 'supercrip' and 'triumph over tragedy' stories convey the Paralympics to a mass audience at the expense of less glamorous narratives associated with typical everyday experiences of disability (Hardin and Hardin 2004; Shakespeare 2000: 6). Part of this 
narrative is what Ellis (2009: 24) referred to as the 'super cripple paradigm'. We argue that this common disability sport narrative is one of the means by which English disabled athletes have been obscured from being considered as representatives of their nation.

In Smith and Thomas' (2015: 107) brief application of established-outsider relations to policy issues and politics relating to Paralympic sport, they use the theory to help explain the unequal power 'relations between disabled people and other members of wider society'. Smith and Thomas (2005: 107) contend that there has been a tendency for disabled people to be characterized and stereotyped in negative ways as outsiders 'whose behaviour constitutes a threat to the 'social' and 'moral order" (Ibid: 107). Beyond this, there has been little use of the theory for understanding aspects of the relationship between sport and disability.

The remainder of this chapter is divided into two substantive sections. In the first we use established-outsider relations as a framework through which to highlight the exclusion of disabled people from the relationship between English national identity and sport throughout history. Following this, the experiences of retired Paralympic athletes (RPAs) are drawn upon to highlight some of the specific difficulties faced by English disabled athletes regarding representing their nation and we explore the national identity implications of the recently emerged Invictus Games.

\section{Sporting Outsiders}

Experiences of sport in school

English schools are the main place where children begin their socialization into the English sporting system. This follows a traditional connection between education and sport in Victorian Britain where there was a focus on sport from an early age based on 
English national identity and Christian values (Watson, Weir and Friend 2005). Organisations such as Sport England work with primary and secondary schools across the nation to enhance and maintain participation in sport both in terms of compulsory Physical Education (PE) as part of the National Curriculum (NC) and in optional extracurricular sport (Sport England 2016). The Department for Culture, Media and Sport (DCMS) encourage young children to develop 'sport as a habit for life' and work with organisations such as the Youth Sport Trust (YST), governing bodies of sport and schools (DCMS 2012: 3). However, there is an assumption that the inclusion of disabled children is taking place, despite $84 \%$ of PE teachers feeling under prepared for working with disabled children (Vickerman and Coates 2009: 137). More recent studies still show that student teachers feel that their initial teacher training on inclusion is ineffective (Coates 2011).

For school age disabled children implementation of the 1944 Education Act led to educational opportunities lauded as "special", but "segregated" in reality. The NC for PE is established for non-disabled children and effectively positions disabled children as "outsiders". The Alliance for Inclusive Education (ALLFIE), is an organization of disabled people which has campaigned for the last 20 years to bring legal changes to education for disabled people into British Law. In March 2016 ALLFIE responded in the following way to the Government's decision to convert all local authority schools into academies by 2020 :

The Government announcement that all existing local authority schools will be converted into academies by 2022 is very likely to increase disability-related discrimination, is bad for inclusion and is a fundamental breach of the Government's obligations under the UN Convention on the 
Rights of Persons with Disabilities. Research carried out individually by the Independent Academies Commission, the Guardian and National Union of Teachers has highlighted academy schools' bad practice including the overuse of exclusions, removing SEN [Special Educational Needs] children from the roll at Key Stage 4 and transferring them into maintained mainstream schools. The Government's announcement alongside the recent change in the law which allows Special Academies to admit SEN children, can only signal a plan to deny SEN children access to mainstream education, and is further evidence of the wider attack on inclusive education practice (ALLFIE 2016).

The established educational system still places disabled children outside of what is deemed "normal" practice. School signals the beginning of lifelong discrimination for disabled people from collective mainstream English identity relating to sport and other areas of education. The experience is one of segregation and disempowerment rather than collective belonging.

\section{The Guttmann effect}

The paternalistic view that disabled people are "helpless" and "different" from the nondisabled majority, which underpins the segregation of the education system for disabled children, is also routinely reinforced in English national media portrayals of disabled people (Barnes and Mercer 2011; Williams-Findlay 2014; Oliver and Barnes 2012). This is reflected in coverage of disability sport too. For instance, during the London 2012 Olympic Games after many of the specific sports features were broadcast on television by the BBC there was an advertisement showing where interested 
individuals could contact their local sports club. This was an innovative way to bring the opportunities to participate in Olympic sports to within everyone's reach. Yet, at the Paralympic Games that followed (broadcast in the UK on Channel 4) no such advertising of opportunities for disabled participants was made available. This is no real surprise considering that since the genesis of disability sport, disabled people have been kept outside of the established non-disabled DSO structure.

A number of academics are highly complementary of the contribution to the inception of the Paralympic Games made by the late Sir Ludwig Guttmann (see Bailey 2008; Brittain 2010; Howe 2008; Legg and Steadward 2011; Smith and Thomas 2016; Thomas and Smith 2009). Guttmann, a non-disabled neurosurgeon, is often lauded as single-handedly being responsible for the beginning of the Games. In 1944 the National Spinal Injuries Centre (NSIC) was opened by Guttmann at the Stoke Mandeville Hospital in Aylesbury, England at the request of the British Government. Sports and physical activity were part of rehabilitating injured ex-military personnel and the first national sports event took place in 1948 at Stoke Mandeville (Howe 2008; Smith and Thomas 2016; Thomas and Smith 2009).

In the following decades the disability sport concept grew until in 1961 the British Sports Association for the Disabled (BSAD) was established by Guttmann in Stoke Mandeville. Although the British Deaf Sports Council (BDSC), the first DSO, was formed over thirty years before in 1930, BSAD was the first one to work closely with the Central Council of Physical Recreation (CCPR) and later the UK Sports Council. Despite the emergence of other impairment specific groups such as British Blind Sport (1976) and Cerebral Palsy Sport (1981), BSAD was seen by the Sports Council as the umbrella DSO (Smith and Thomas 2016). BSAD included a range of impairment groups within their sports event structures (Thomas and Smith 2009). A crucial turning 
point in the exclusion of disabled sports people in England came when the UK Sports Council (later reformulated as UK Sport and councils for each of the home nations, e.g. Sport England, Sport Scotland, etc.) began to support the transition of BSAD from a membership sports event organizer into an advisory body to local authorities, schools and mainstream governing bodies of sport. This role was at its zenith in the 1980 s and 1990s (Braye 2014). In 1998 the English Federation of Disability Sport (EFDS) was formed to replace BSAD, though its structure of non-disabled staff advising on disability issues remained; a paternalistic legacy of what we call "the Guttmann effect".

Peers (2009) is critical of the way that the disabled athletes involved in this Paralympic embryo remained unknown, whilst Guttmann himself became an iconic British figure of benevolence towards disabled people. Brittain and Beacom (2016) criticize Peers' apparent lack of appreciation for Guttmann's contribution to disability sport. However, these authors fail to acknowledge that Peers' (2009) argument is less about Guttmann's input and more about the exclusion, or non-recognition, of disabled people demonstrating that the disabled people involved in the inception of the Paralympics remain anonymous.

One of the consequences of the Guttmann effect is that DSOs throughout the UK are also sites of exclusion for disabled people. On 2 June 2016 an article by John Pring on the Disability News Service (DNS) website reported on the findings from a survey which established the numbers of disabled people working in 11 DSOs. Among these DSOs only 27 employees out of 163 (16.6\%) identified as disabled (Pring, 2016). Two of the DSOs surveyed were the British Paralympic Association (BPA) and the EFDS. Among the nine board members of the BPA only one is a disabled person, and only three of its 33 paid staff identify as disabled. The BPA arguably has the largest pool of disabled people from which to recruit board members and employees. At the 
London 2012 Paralympic Games there were 288 British Paralympic athletes and there are over a thousand retired British Paralympians (BBC 2012). Furthermore, thousands of English athletes of all levels have passed through the EFDS segregated local, regional and national events and are known, by name and address, to the organization. Given these statistics, it is puzzling that DSOs struggle to recruit disabled people.

The EFDS, which is founded, funded and actively supported by Sport England, has only three disabled people on its board of 10 , and only six full-time disabled staff out of 25. The non-disabled Chief Executive of EFDS, Barry Horne, states that the organisation are:

constantly seeking ways to improve our own equality and diversity, especially with disabled people... [and that they work] to increase disabled people's inclusion at every level and support other organisations to do the same. [He said] Although our charity name immediately determines the nature of our work with disabled people, it does not mean that disabled people automatically apply for positions. Just as the word 'sport' in the charity's name does not mean we only employ 'sporty' people, the word 'disability' does not guarantee applications from disabled candidates. But we always actively encourage disabled people to apply for our vacancies (Pring 2016).

Notwithstanding "active encouragement", a further survey would be useful to establish at what level the disabled employees of these DSOs operate to see whether they have administrative roles or policy making roles. If the former is true, then the implication is 
that the BPA and EFDS do not value personal experience of disability when making appointments and ironically they seem to regard disabled people as outsiders.

\section{Upside-down: the lack of opportunities for English disabled athletes to represent their nation}

Bearing in mind the context provided in the previous section, in this section we draw upon the experiences of RPAs in order to demonstrate the lack of opportunities for English disabled athletes to represent England and the ways in which they have been obscured from the strong relationship that exists between non-disabled sport and English national identity.

The opportunities for English disabled athletes to represent their nation are primarily as British athletes in the Paralympic Games and secondly as English athletes in five sports at the Commonwealth Games (CG) including: athletics, swimming, powerlifting, lawn bowls and track cycling. ${ }^{1}$ There are, of course opportunities to represent England in sport competitions outside of this structure, but the prestige awarded to disability sport external to "the Games" is minimal, unlike that for "mainstream" sport. At this point, then, it is worth considering the structure of sport development in England in order to compare and contrast the strategies and opportunities for non-disabled and disabled people. To do so, we draw attention to the "sports development continuum", a model that represents a person's involvement in sport by referring to what stage they are at, and to highlight the route that an athlete can take to become an elite performer.

\footnotetext{
${ }^{1}$ Sport for disabled people is sometimes referred to as "Para-Sport" and four of these sports events were first included in the 2002 Commonwealth Games (CG) in Manchester, UK. The five sports listed above were first included in the 2014 CG in Glasgow, UK, totaling 22 medal events (BPA 2012).
} 
For non-disabled people this strategy is an effective way to monitor progress and activity levels with clear guidance for progression; however, as we explain below, this structure is not implemented in the same way for disabled people. To illustrate how this is so, in Figure 9.1 (below) we have adapted the traditional Sport Development Continuum (from Hylton 2013, p.5) to include what we call the "Disability Sports Development (Dis) continuum".

\section{<FIGURE 9.1 HERE>}

To explain, the structure of sport for non-disabled people is illustrated in pyramid format including the following levels: foundation (at the bottom); participation; performance; and excellence (at the top). The pathways up and down the pyramid are well-established for all non-disabled sports and age groups. The premise of the pyramid structure is that a broad participation base is a necessary pool from which to draw future elite athletes.

In contrast, the structure of sport for disabled people is a precariously balanced upside-down pyramid with excellence at the top in the format of the Paralympics and increasingly in the CG, with limited opportunities below. The pathways are unclear, and where they do exist they are not for all disabled people, and not in all sports. Paralympic participation itself is limited only to those disabled people for whom classification by impairment or function is achievable. Beyond this, it is worth noting that in those fleeting situations when disabled and non-disabled athletes share the same space in the name of "team unity", there is evidence to suggest that notions of equality were hollow and without substance: 
I very much disliked the way British Swimming treated us like second class citizens, which certainly made me feel more like an individual rather than being part of a bigger picture. (Bob, competed in five Paralympic Games, three World and six European championships)

Bob is experiencing the problem of the BPA, the IPC, and British Swimming attempting to merge national athletes within a British Olympic Association (BOA) and International Olympic Committee (IOC) framework. It seems right to do so, but rather than breaking down barriers it can also accentuate them for the disabled athletes (Braye, Dixon and Gibbons 2015). Craig also experienced attempts at the inclusion of Paralympic athletes within an Olympic Games:

In 2004 the Paralympic kit was a cheap version of the Olympic kit, and even at the Olympics where we were told by the administration of the team that we were, "full members of the team", it was quite obvious that we were not, I handed back the scraps of kit they provided. (Craig, competed in one Paralympic Games and one Commonwealth Games)

These experiences suggest that whilst enjoying sport at the highest level, disabled athletes also experience discrimination within their own national squads, and their own governing bodies of sport, when amalgamated within non-disabled structures.

In 1945 George Orwell famously referred to mainstream (non-disabled sport) as 'war minus the shooting' (see Orwell and Angus 1970). Moreover, Hoberman (1984) referred to male elite athletes who represent their nation at sport as 'proxy warriors' for 
their nation referring to how male international sport is often conceived of as a "proxy war' (see Bairner 2001). However, there appears to be a suggestion that, in some cases at least, the identity of being a disabled person overrides any nationalistic feelings and any sense expressed by non-disabled athletes that they are proxy warriors. As Mary explains:

I don't feel strongly enough about the whole nationality thing to comment on the need/desire for nation specific sporting opportunities. The struggle for equality for/by disabled people outside sport can be related to the struggle for equality in the US for/by black people. I just wish current Paralympians felt able to challenge the status quo in the way that Tommie Smith and John Carlos did at the 1968 Olympics. Sadly Government sponsorship appears to be silencing any dissent [from Paralympians]. Personally the situation is even worse for disabled people with more significant impairments; they no longer have the opportunity to compete at any level thanks to the IPC's desperation for a profile slightly more equal to the Olympics. Those athletes with more significant impairments have always been made to feel second best in disability sport and my feeling is that this is reflecting across society too. Those who cost the most, but financially contribute the least are less valuable/worthy; back to eugenic ideology I'm afraid (Mary).

Mary goes beyond just personal feelings of national identity and highlights the problems for disabled people in wider society, particularly those with more severe impairments. The paradox implied in her comments suggests that Paralympians are 
competing for a nation that discriminates against them. Other Paralympians, however, saw no national identity, or discrimination issues and focused primarily on the competitive element of their sports participation, as Jim suggests here:

As a swimmer I first represented the region I resided in; from there I then went on to represent GB. I don't ever remember being selected to swim for England and I must say whenever asked who I swam for I would say GB rather than England. Either way it was an honour to represent my country (Jim, competed in three Paralympic Games).

In contrast to Mary, Jim clearly regards himself as a proxy warrior for the nation, but for Britain rather than England.

The upside-down structure referred to above is evident in the comments that these Paralympians are making. The presence of elite performers (Paralympic athletes) provides the impression that the disabled sports system is working and available to all. It fails to highlight that there is no system in place to support many disabled people, especially those with more severe impairments. Paralympic athletes are "symbols of failure" in the sense that they help to perpetuate myths of universal opportunity and competent systems of sports development practice. ${ }^{2}$ Craig comments on this particular issue:

I have competed for GB, and England at Commonwealth Games, but there is not really an opportunity in wheelchair and disability sport in

\footnotetext{
2 The term "symbols of failure" was used by Ellis Cashmore to define black sports stars (Cashmore 2005: 205).
} 
general to compete for class/house, school, town, county, region or nation, which there is for non-disabled people. This is partly the numbers game, but partly the non-inclusive nature of that below GB (Craig).

It would appear that for disabled athletes representation for Great Britain is perhaps easier to attain than competition at other levels, though in some sports CG representation is not available to disabled athletes, and for others this is relatively new. Opportunities for disabled athletes to represent England are few and far between. Bob, a swimmer, competed in five Paralympic Games from Seoul 1988 to Athens 2004. During that time he competed in three World Championships and six European Championships, all as part of a GB squad, he states:

I have always considered myself as representing GB rather than a home country but, as you state, I never had the opportunity to go to a Commonwealth Games. I was happy to be part of GB. (Bob)

That opportunity is not necessarily something that would have been welcomed by some competitors, as Roy explains:

I have been delighted as a paraplegic athlete to represent Great Britain in the Paralympics and see absolutely no good reason to separate our individual home countries (Roy, competed in two Paralympic Games). 
The dominant view is that these Paralympians associated themselves primarily with sport and because GB has been the main unit of representation, British rather and English. Therefore, English nationalism and national identity appeared not to be of major concern for some of our participants but this was only because their opportunities to represent England were minimal. They had rarely (if ever) been given the opportunity to represent England and consequently (when pushed for an answer) affiliated themselves with Great Britain. In addition, participants have explained that being disabled in England means fighting the system within the country rather than embracing what it means to be English. Centrally, because those participants feel like "outsiders" to the established order, they believe that any kind of trickle-down opportunities that emerge for disabled people through sport are more likely created by chance than by design, and do not see themselves as representatives of the nation.

As participants like Mary have explained, major disability sports events such as the Paralympic Games do not cater for disabled people with the most significant impairments, and this is also true of new and emerging media friendly disability sports events such as the "Invictus Games". Founded by Prince Harry in 2014, these Paralympic style sports events are designed for injured ex-military personnel and they have developed at a rapid rate, already securing television coverage (Invictus Games 2016). Prince Harry as the figurehead of the Invictus Games has managed to secure the support of a broad range of non-disabled celebrities who use the Invictus Games motto "I am Invictus" to demonstrate their admiration for the athletes involved (BBC 2016). The Invictus Games is, like the Paralympics, masking the reality of poor sports opportunities for most disabled people. The Invictus competitors will have passed through a mainstream educational system which included PE, physical activity and competitive sport, unlike many disabled children in contemporary England. 
In addition to this, the Invictus Game is closely linked to the military and this on the face of it, would lead one to expect it to have a strong potential for the expression of national identity by enabling disabled athletes to be regarded as proxy warriors for their nation. However, this is not the case because Invictus celebrates the common disability sport narrative of 'individualistic achievement in the face of adversity' rather than enabling disabled athletes an opportunity to represent their nation. Invictus, from the Latin 'unconquered' or 'undefeated', implies the 'overcoming' narrative we referred to earlier (see Braye et al, 2013; Ellis 2009; Hardin and Hardin 2004; Peers, 2009; Shakespeare 2000). The wounded ex-military personnel sports avenue is closely linked to UK programmes and charities such as the Royal British Legion's 'The Battle Back Centre' and the UK military charity 'Help for Heroes' (Royal British Legion 2016; Help for Heroes 2016). This is not necessarily a criticism of the efforts of the wounded individuals to rehabilitate themselves, but it is important to note that the style of the processes on offer, and the media coverage, reinforce negative disability stereotypes rather than selling disabled sportspeople as proxy warriors for their nation.

\section{Conclusion}

In this chapter we have argued that because sportspeople with disabilities are largely excluded from mainstream organisations, events and development pathways, they are likely to eschew a strong relationship between their own sports performance and English national identity. In order to highlight this we used Elias and Scotson's (1994) theory of established-outsider relations setting out how disabled people have traditionally experienced being outsiders. We focused on how experiences of sport in school in England mirrored the history of segregation in the education of disabled people in the UK more broadly. This underpinned what we termed "the Guttmann 
effect" through which we explained how disabled people were excluded from the genesis of disability sport and have subsequently remained obscured from the development of sport for disabled people in England ever since, especially the development of DSOs. We argued that the segregated education system for disabled people and the Guttmann effect have both led to the current structure of disabled sport in England (the sport development continuum) being "upside-down" in comparison with that for non-disabled people. We have suggested that there is a separate structure for disabled people in sport, namely, the "disability sports development (dis)continuum".

We have highlighted that elite disabled athletes have few opportunities to compete for England and therefore expressions of English national identity. The lower down the disability sports development (dis)continuum, particularly at school age, the opportunities for participation in sport become less apparent. The Guttmann effect is a reality which is proven by the lack of disabled board members and employees within organisations such as the BPA and EFDS. The experiences of the RPAs showed how English disabled athletes have been ostracized from representing their nation. The Invictus Games' use of non-disabled celebrities led by the British figurehead Prince Harry is the latest example of how disabled people remain largely anonymous outsiders in the development of DSOs and events. This is something that has previously been suggested by Peers (2009) in relation to the Paralympic Movement. Invictus also highlights how individualistic achievement in the face of adversity is valued more highly when it comes to disability sport than enabling disabled athletes an opportunity to represent their nation.

\section{References}


ALLFIE (2016) ALLFIE's response to the purpose of Education inquiry. Available at: http://www.allfie.org.uk/ (Accessed Jun. 2016).

Anderson, B. (1991) Imagined Communities: Reflections on the Origins and Spread of Nationalism. London, Verso.

Bailey, S. (2008) Athlete first: A history of the Paralympic movement. Chichester, John Wiley \& Sons.

Bairner, A. (2001) Sport, Nationalism, and Globalization: European and North American perspectives. Albany, State University of New York Press.

BALASA (2016) About us: a brief history of BALASA. Available at: https://sites.google.com/a/balasa.org.uk/main/About-us (Accessed Jun. 2016).

Barnes, C. and Mercer, G. (2011) Exploring Disability: a sociological introduction.

Cambridge, Polity Press.

BBC (2012) Paralympics GB: Who will compete for Great Britain in London? Available at: http://www.bbc.co.uk/sport/disability-sport/18306674 (Accessed Jun. 2016). BBC (2016) Invictus Games Orlando 2016. Available at: http://www.bbc.co.uk/programmes/b04hgs2m (Accessed Jun. 2016).

Braye, S. (2014) 'Meet my Exes: Theological reflections on disability and Paralympic sport - a continuum of ephemeral deaths and eternal resurrection', Sports, Religion and Disability (Special Edition), Journal of Disability and Religion, 18(2), 127-141.

Braye, S., Dixon, K., and Gibbons, T. (2013) Braye, S., Dixon, K. and Gibbons, T. (2013) 'A mockery of equality': An exploratory investigation into disabled activists' views of the Paralympic Games, Disability \& Society, 28(7), 984-996. 
Braye, S., Dixon, K., and Gibbons, T. (2015) The 2012 Paralympics and perceptions of disability in the UK. In K. Dixon \& T. Gibbons (Eds.) The Impact of the London 2012 Olympic \& Paralympic Games: Diminishing Contrasts, Increasing Varieties. Hampshire, Palgrave, pp.15-34.

Braye, S, Gibbons, T. \& Dixon, K. (2013) 'Disability 'rights' or 'wrongs'? The claims of the International Paralympic Committee, the London 2012 Paralympics and disability rights in the UK', Sociological Research Online, http://www.socresonline.org.uk/18/3/16.html

Brittain, I. (2010) The Paralympic Games explained. London: Routledge.

Brittain, I., and Beacom, A. (2016) Leveraging the London 2012 Paralympic Games: What Legacy for Disabled People? Journal of Sport and Social Issues, 40(3) pp.1-23.

British Paralympic Association (2012) Glasgow 2014 to stage bigges ever commonwealth para-sport programme. Available at:

https://www.paralympic.org/news/glasgow-2014-stage-biggest-ever-commonwealthpara-sport-programme (Accessed Jul. 2016).

Cashmore, E. (2005) Making Sense of Sports (Fourth Edition). London, Routledge.

Coates, J.K. (2011) Teaching inclusively: are secondary physical education student teachers sufficiently prepared to teach in inclusive environments? Physical Education and Sport Pedegogy, 17(4), 349-365.

DCMS (2012) Creating a sporting habit for life: a new youth sport strategy. Available at: https://www.sportengland.org/media/3487/dcms-creating-a-sporting-habitfor-life-1.pdf (Accessed Jul. 2016).

Elias, N. and Scotson, J. L. (1994) The Established and the Outsiders: A Sociological Inquiry into Community Problems. London, Frank Cass. 
Ellis, K. (2009) Beyond the aww factor: Human interest profiles of Paralympians and the media navigation of physical difference and social stigma. Asia Pacific Media Educator, 19 (4), 23-35.

Gibbons, T. (2010) Contrasting representations of Englishness during FIFA World Cup Finals. Sport in History, 30 (3), 422-446.

Gibbons, T. (2014) English National Identity and Football Fan Culture: Who are ya? Surrey, Ashgate.

Gibson, O. (2012) Drop the word 'disabled' from Games coverage, demands Paralympics committee president. The Guardian, 26 August 2012. Available at: http://www.theguardian.com/sport/2012/aug/26/paralympics-philip-cravendisabled-disability, (Accessed Feb. 2014).

Hardin, M. M., and B. Hardin. 2004. The 'supercrip' in sport media: Wheelchair athletes discuss hegemony's disabled hero. Sociology of Sport Online, 7 (1), http://physed.otag- o.ac.nz/sosol/v7i1/v7i1_1.html

Help for Heroes (2016) Homepage. Available at: http://www.helpforheroes.org.uk/ (Accessed Aug. 2016).

Hoberman, J. M. (1984) Sport and Political Ideology. Texas, University of Texas Press. Howe, P. D. (2008) The Cultural Politics of the Paralympic Movement, through an anthropological lens. London, Routledge.

Hylton, K. (2013) Introduction. In K. Hylton (Ed.) Sport Development: policy, process and practice (Third Edition). London, Routledge, pp.1-10.

Invictus Games (2016) Available at: https://invictusgamesfoundation.org/ (Accessed Jun. 2016). 
Legg, D., and R. Steadward. (2011) The Paralympic games and 60 years of change (1948-2008): Unification and restructuring from a disability and medical model to sport-based competition. Sport in Society, 14 (9), 1099-1115.

Maguire, J. and Poulton, E. (1999) European Identity Politics in Euro 96: Invented Traditions and National Habitus Codes. International Review for the Sociology of Sport, 34 (1) 17-29.

Oliver and Barnes (2012) The New Politics of Disablement. Basingstoke, Palgrave Macmillan.

Orwell, S. and Angus, I. (1970) The Collected Essays, Journalism and Letters of George Orwell (Volume IV): In front of your nose. Harmondsworth, Penguin.

Peers, D. (2009) (Dis)empowering Paralympic histories: absent athletes and disabling discourses. Disability and Society, 24(5), 653-665.

Pring, J. (2016) 'Paralympic movement still run by non-disabled people, survey shows'. Disability News Service. Available at:

http://www.disabilitynewsservice.com/paralympic-movement-still-run-by-nondisabled-people-survey-shows/ (Accessed Jun. 2016).

Roulstone, A. and Mason-Bish, H. (2013) Disability, Hate Crime and Violence. London, Routledge.

Royal British Legion (2016) The Battle Back Centre. Available at: http://www.britishlegion.org.uk/get-support/physical-health/the-battle-backcentre/ (Accessed Aug. 2016).

Shakespeare, T. (2000) Help. Birmingham, Venture Press.

Smith, A. and Thomas, N. (2016) Sport, Disability and the Paralympics. In B. Houlihan and D. Malcolm (Eds.) Sport and Society (Third Edition). London, Sage, pp.199221. 
Smith, A. and Thomas, N. (2015) The politics and policy of inclusion and technology in Paralympic sport: beyond Pistorius. In D. Bloyce and A. Smith (Eds.) The 'Olympic and Paralympic' Effect on Public Policy, pp. 97-110.

Sport England (2016) Our Work: Children and Young People. Available at: https://www.sportengland.org/our-work/children-and-young-people/ (Accessed Jun. 2016).

Thomas, N. and Smith, A. (2009) Disability, sport and society, an introduction. London, Routledge.

Turner, D. (2012) Disability in Eighteenth-Century England: Imagining Physical Impairment. London, Routledge.

Vickerman, P., and Coates, J.K. (2009) Trainee and recently qualified physical education teachers' perspectives on including children with special educational needs. Physical Education and Sport Pedagogy, 14(2), 137-153.

Watson, N., Weir, S., and Friend, S. (2005) The development of muscular Christianity in Victorian Britain and beyond. Journal of Religion and Society, 7, 1-21.

Williams-Findlay, R. (2014) The representation of disabled people in the news media. In J. Swain, S. French, C. Barnes, and N. Thomas, Disabling Barriers Enabling Environments (Third Edition). London, Sage, pp.107-113. 